\title{
HOMOPHONY RE-VISITED
}

\author{
Ha Quang Nang* \\ Vietnam Institute of Lexicography and Encyclopedia, Hang Chuoi, Hai Ba Trung, Hanoi, Vietnam
}

Received 16 October 2017

Revised 17 November 2017; Accepted 23 November 2017

\begin{abstract}
Homophony is a common phenomenon in languages and various studies on homophony have been conducted. However, homophones are just generally understood as different lexical units with similar or identical pronunciation but different meanings. This paper analyzes different views on homophones in existing literature and presents a comprehensive, complete and scientific view on homophony in languages.

Keywords: homonym, homonymy, homophone, homophony, homograph
\end{abstract}

\section{Statement of the problem}

Homophony is phonetic duplication of at least two linguistic units. Homonyms, pursuant to the most conventional and common understanding, are words having the same pronunciation, but different meanings. Homophony occurs in all languages as a natural necessity, since linguistic signs (the signifiers) are limited while what they represent of the real world (the signified) is infinite.

Although all authors in existing literature have the same understanding of homophony, there has not been a uniformed definition of homonyms. The most general definition, among dozens of these, recognizes uniformity of language units in terms of representation and their difference in terms of meanings. However, there is serious disagreement as to which elements of the signifier and the signified should be regarded as fundamental causes of homophony and how they are related to each other. There could be an alternative solution: homophones may be considered words or linguitsic units of different levels.

Bally's definition of homophones was one of the earliest, which states, "two signs sharing the same signified but represented by different signifiers are homophones"

${ }^{*}$ Tel.: 84-944040808

Email: nanghaquang@gmail.com
(Bally, 1955). There cannot be agreement to the contrary, but this definition seems too broad compared to all other definitions of homophones, as it encompasses signs at all language levels. In addition, it is too generic, since it does not clarify which elements of the signifier and the signified can be reliable for identifying homophony. How to interpret "the same signified" is not an easy question as the signifier of linguistic signs can be either sound or writing. In languages of different types, at lexical level, there always exist:

- Linguistic units sharing the same phonetic (i.e. the same pronunciation) and spelling forms (i.e. homonyms, in the strictest sense of this term);

- Linguistic units sharing the same phonetic form (i.e. the same pronunciation) but having different spellings (i.e. homophones);

- Linguistic units sharing the same spelling, but having different phonetic forms (i.e. different ways of pronunciation, or homographs).

In dealing with homophony, how should we treat this situation? Could we treat homophones as linguistic units of different levels? These are the questions to which this paper aims to respond, apart from presenting different views of homophony, including our own position. 


\section{Different views of homophony}

Not only Bally (1955) but several other authors also talk about homophony. Bloomfield (1968) deals with homophony of "different language forms", while Richter (1926) mentions homophony of several "sound sequences", and Smirnitskij (1948) talks of homophony of "linguistic units". It is possible to interpret homophony as such (Maslove, 1963), but most other authors (Slitterlin, 1907; Il'ish, 1948; Filin, 1960; Tauli, 1968; amongst others), define homophones as words or morphs, or they finally end up dealing with homophony at word level (Moloshnaja, 1960; Korovina, 1962; Pacak, 1963). Perhaps, then, the term "homophones" can only be used to refer to words as units at lexical level.

Next, it is necessary to clarify what can be understood as the identicality among the signifiers, and what are differences in the signified. In existing literature, the identicality of the signifiers is primarily interpreted as the identical sounds of homophones (Shajkevich, 1950; Marujio, 1960; Stepanov, 1966). Several authors also claim that identical spelling cannot be regarded as signals of secondary homophony because written language is merely a product of spoken language (Smirnitskij, 1956; Levkovskjaa, 1956; Shajkevich, 1962; Prorokova, 1966; Tyshler, 1988). That is not accurate. Phenomena in written language are apparently related to linguistic phenomena in general, so they must be considered linguistically as phenomena of spoken language (Leont'ev, 1964; Amirova, 1977). Therefore, it is clear that definitions of homophony cannot but consider the sameness in the written forms of words and those words that only share the same spelling (e.g. tear 1 tirl [a drop of clear saline fluid secreted by the lacrimal gland and diffused between the eye and eyelids to moisten the parts and facilitate their motion] and tear, [ter]- [to separate parts of or pull apart by force], which do not need to be excluded from the list of homophones.

Other contrastive views also exist, which posit that the sameness of the signifiers is merely graphic identicality (spelling/writing) while words' phonetic forms are disregarded. This seems to enjoy very little support, as it only pays attention to the written forms of language (Saranda, 1968). However, this position seems to linger vaguely in most applied research works, primarily studies on text automation. Those studies seem to rely largely on data of written language, general or specific dictionaries in which language is accessed in written forms, and homophones are considered only when they share the same spelling. This view is incomplete as it does not consider a major element of the signifier - the phonetic forms of words. Consequently, homophones as acoustic variants of language do not enjoy identical spellings in written forms (e.g., pale \& pail in English; chong (đèn) (lit. leave the light on late at night) trong (ngoài) (in vs. out), châu (báu) (pearl) - trâu (bò) (buffalo), giong/rong/dong in Vietnamese, and they will be excluded from homophonic relations.

Recognition of the independence of the spoken and written forms of language reveals that the signified of linguistic signs can appear in either form - the phonetic form of words (among various acoustic variations of language) and the graphic form of words (in spelling/writing). Therefore, these possibilities must be considered when dealing with identicality of the signifiers. Most authors acknowledge the identicality in both sounds and spellings of the words in question, and consider them signals of homophony.

Nevertheless, there remain unclear issues, e.g. how these signals correlate, whether both of them must always simultaneously exist, or it suffices if only one of them appears.

Some authors believe that identical 
spelling is a compulsory signal and must accompany identical pronunciation (Il'ish, 1948; Shanskij, 1964; Akhtiamov, 1966; Arnold, 1959). They believe that the two formal signals of homophony are phonetic and spelling identicality of the signified. These signals are inter-related. However, if this approach held, words that share the same pronunciation (e.g. pale vs. pail) or the same spelling (e.g. tear vs. tear), i.e. they are only similar in terms of sound or spelling, would not be included in the lists of homophones.

Still, other authors believe that identical spelling is unnecessary. It only adds to the compulsory requirement that the words must share the same phonetic forms (Gleenough, Kittredge 1961). This, in essence, is no different from the earlier approach that underestimates the importance of identical spelling, which, again, excludes words sharing the same spelling from the list of homophones.

Finally, some authors attach the same importance to both phonetic and spelling identicality. According to these authors, formal signals of homophony seem to exist in an or-relation. However, they do not clearly explain that or-relation, or whether it is a strict (exclusive) relation or a normal one. In the former case, possibly only one of these signals, i.e. phonetic identicality, or graphic identicality, is sufficient rather than both for the identification of homophones. One example is by Arakin (1958), who defines homophones as words "sharing the same sounds or the same graphic representations (spelling)". This definition would exclude words that are identical in both sounds and spellings such as deal (quantity) and deal ${ }_{2}$ (contract), i.e. words that cannot be suspected as non-homophones. In the latter, i.e. when the or-relation is normal and weak, only one of these two formal signals is sufficient for identifying homophones, whatever it is. Yet the simultaneous occurence of both these signals is not taken into consideration. This view is also reflected in Koonin's definition (1940), which states that homophones are words sharing the same pronunciation and spelling. Such interpretation of the signifiers is the only accurate one since it allows for inclusion of homophones in both sounds and spellings. The correspondence of formal signals of homophony in this approach can be captured in this logical formula: $\mathrm{I}=\mathrm{P} \mathrm{O}$ $\mathrm{S}$, where I stands for Identical form of words, $\mathrm{P}$ for Phonetic identicality, S for Spelling, and $\mathrm{O}$ is the or-relation; homophony occurs when both $\mathrm{P}$ and $\mathrm{S}$ are present. It should be added that while all authors agree on the same explanation of spelling identicality, they seem to differ in their views to acoustic identicality. Some call acoustic identicality phonetic identicality (Bloomfield, 1968) or phonemic identicality (Tauli, 1968) or superficial sounds (Smirnitskij, 1948) of word forms, while others call them identicality of "sound structure" of words (Vinogradov, 1960) or of allophones of words (Durovic, 1953), or "superficial coincidence of sounds" (Akhmanova, 1957), or "the same acoustic impression of series of sounds" (Richter, 1926), or merely similar sounds (Smirnitskij, 1956) or similar pronunciation (Greenough, Kittredge, 1961; Il'ish 1948). In communication, homophony could be the first barrier to the listener rather than the speaker, so such definitions need to pay attention to acoustic identicality, i.e. the phonetic form of words and their sounds rather than how they are articulated or uttered. In this line, spelling identicality must also be interpreted as spelling (graphic) identicality, or the sameness of the letters that represent the words.

Definitions of homophones contain one point that relates to the difference in the signified. It is strange that a number of authors do not pay attention to this point. However, in most cases, definitions 
also include differentiation of meanings. Moreover, they only deal with differences in lexical meanings (denotation) and these differences are sometimes directly mentioned in definitions (Skeat, 1978; Marrujo, 1960) or drawn out of contexts (Budagov, 1958). In this approach, only one of the elements of the signified is paid attention - that is, the lexical meanings, while grammatical meanings are underestimated. Thus, words like fall (v) and fall (n), or round (adj) and round (adv), loi (n., gum) - lơi (adj., beneficial); lang (n.) [as in khoai lang (sweet potato)] - lang (adj., promiscuous or having white patches on skin, hair or fur) are not considered homophones. These words are apparently identical in form, and differ only in their grammatical meanings (General Linguistics, 1972).

In some works, differences in the signified are merely regarded as differences in grammatical meanings - by and large, these are differences in terms of parts of speech (Moloshnaja 1960; Korovina 1962). Disregarding differences in lexical meanings will ultimately result in words which are identical in form and different in lexical meanings (e.g. palm (part of a hand) and

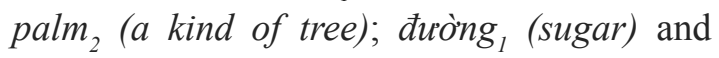
duờng ${ }_{2}$ (way, road) being excluded from homophones.

Other works, however, regard differences in both lexical and grammatical meanings are signals of homophony. Pacak (1963), for instance, points out "meanings that are completely different and can be different syntactic functions". Nevertheless, this definition does not make very clear the features of relations among these signals. While both lexical and grammatical meanings are included in the conceptualization of the signified, differences in words' grammatical meanings should be regarded as less important signals than differences in lexical meanings in the consideration of homophony. The occurence of either of these two signals, or their simultaneous presence must be considered characteristics of homophony. The reciprocal relations among these signals are clearly presented in Durovic's definition (1953) who defines homophones as two or more words with identical phonetic sequence but with semantic or grammatical differences or both.

Thus, content signals as well as formal signals of homophony are in noncorresponding relation. This relation can be represented by the formula $D-M_{1} R M_{n}$ where D stands for differences in content, $M_{1} M_{n}$ differences in corresponding lexical and grammatical meanings, and $\mathrm{R}$ represents selective relation. The above accounts clarify 4 major signals of homophony: 2 in form (identicality in sounds and spellings) and 2 in content, which are lexical and grammatical differences). On such a basis, it is clear that the 4 signals are necessary and sufficient for identifying the existence or non-existence of homophonic relation among words. However, on the one hand, it is necessary to clarify features of relations among formal signals of homophony, and on the other hand, relations among content signals. Homophonic relations among words can only arise in case they are identical in terms of the signifier while differing in terms of the content (the signified).

\section{A scientific understanding of homophones}

Thus, definitions of homophones are based on both formal identicality as well as meaning differences among words under investigation. Homophony, in conventional interpretation, is a phenomenon which is subject to rigorous control within a language system. Homophony among languages, i.e., the similarity of words in different language systems, is concerned with a completely different aspect. This phenomenon is specially studied in a subfield of linguistics - contrastive linguistics - and definitely this subfield of linguistics must have 
its own terminology for various concepts. Homophones, in the strictest sense of the word - concern words of the same language.

Homophones can also be words related to different historical periods of the same language (cf., ngặt meaning poor in old Vietnamese and ngặt meaning rigorous, wellsupported [argument] in modern Vietnamese). Also, it is impossible to contrast the phonetic forms of words of different periods. They do not occur in speech simultaneously and cannot be in any relation to one another. Signals of homophony at lexeme level and word level differ, so it is impossible to produce a single definition for both.

Considering all the above, it is possible to define homophones (at lexeme level) as words of the same language at the same period of existence which are identical with regards to elements of the signifier, i.e. identical sound and writing in all representations but differ in elements of the signified, i.e. lexical and grammatical meanings. Based on this definition, homophones can be identified in accordance with the following criteria:

a. Words are considered homophones when they have identical signifiers (including both sound and spelling) but differ in one of the elements of the signified, i.e. word's lexical and grammatical meanings;

b. Differences in lexical meanings are interpreted as the absence of derivative relationship between the signified, i.e. when one of the meanings of one word is not in any derivative relation with one of the meanings of the other word. Differences in lexical meanings form a basis for homophony.

c. Differences in grammatical meaning are differences in common grammatical features of the whole class of words, i.e. in parts of speech.

Like synonyms and other lexicogrammatical groups, homophones fall into a correlative category. A word can be in homophonic category only when it correlates to another (or others) which has/ have the same form but different meanings. Thus, homophones occur in language not as individuals butas groups. Also, the fundamental structural units having homophonic relation are not isolated words but a group of words which enjoy homophonic relation and form a homophonic sequence (just like synonyms that make up a synonymous sequence rather than individual words).

\section{References}

\section{Vietnamese}

Đỗ Hữu Châu (1986). Tư vưng - ngũ nghĩa tiếng Việt (Vietnamese lexicon - semantics). Hà Nội: Nxb. Giáo dục.

Nguyễn Thiện Giáp (1971). Hiện tượng đồng âm trong tiếng Việt (Homophony in Vietnamese). Ngôn ngũ (Linguistics) No.4.

Nguyễn Thiện Giáp (1983). Tù vựng học tiếng Việt (Vietnamese lexicology). Hà Nội: Nxb. Đại học và Trung học chuyên nghiệp.

\section{English}

Greenough G. B., Kittredge G. L. (1961). Words and Their Ways in English Speech. New York.

Koonin A. (1940). English Lexicology. Moscow.

Pacak M. (1963). Homographs: Their Classification and Identification // Vistas in Information Handling. Washington, Vol. 1, p. 111 - 140.

Skeat W. W (1978). An Etymological Dictionary of the English Language. Oxford.

Tauli V. (1968). Introduction to a Theory of Language Planning. Uppsala.

\section{German}

Richter E. (1926). Uber Homonymie (On homonymy). Leipzig, s. 167 - 201.

\section{Russian}

Амирова Т. А. (1977). К истории и теории графемики (On history and theory of graphemes). Moscow.

Аракин В. Д. (1958). Омонимы в английском языке (Homonyms in English)// ИЯШ, с. 3 -11.

Арнольд И. В. (1959). Лексикология современного английского языка (Modern English lexicology). Moscow.

Ахманова О. С. (1957). Очерки по общей в руской лексикологии (Essays on general Russian lexicology). Moscow.

Ахтямов М.X. (1966). Проблемь омонимии в современном литературном башкирском языке 
(Problems of Homonymy in Modern Literary Bashkir Language). Автореф. канд. дис. Moscow.

Балли Ш. (1955). Общзая лингвистика и вопросы французского языка (General Linguistics and Problems in French). Moscow.

Блумфилд Л. (1968). Язык (Language). Moscow.

Виноградов В. В (1960). Об омонимии и смежных явлениях (On homonymy and related phenomena)// ВЯ, N. 5, c. 3 - 17.

Ильиш Б. А. (1948). Современный аглийский язык. Теоретический курс (Modern English - a theoretical course). Moscow.

Коровина Г. И (1962). Построение правин различения омонимии при помощии машины (Developing rules for machine differentiation of homonyms) // Проблемы кибернетики. Вып. 7, с. 225 - 228.

Корчагина Т. И (1984). Омонимия в современном японском языке (Homonym in modern Japanese). Moscow.

Кочерган М. П (1981). Лексическая сочетаемость омонимов и лингвистический статус омонимии (Lexical compatibility of homonyms and linguistic status of homonymy)// ФН. No. 5, c. 47 - 55.

Левковская К. А (1956). Лексикология немеичкого языка (German lexicology). Moscow.

Леонтьев А. А (1964). Некоторые вопросы лингвистической теории письма (Some questions of the linguistic theory of writing) // Вопросы общего языкознония, М.,

Лингвистический эничилопедический словарь (Linguisic encyclopedia) (Главный редактор В. Н Ярцева). Москва “Советская Энциклопедия”, 1990.

Малаховский Л. В (1990). Теория лексической $u$ грамматической омонимии (Theory on lexical and grammatical homonymy). Ленинград "НАУКА", Ленинградское отделение.

Марузо Ж. (1960). Словарь лингвистических терминов (Dictionary of linguistic terms). Moscow.

Маслов Ю. С (1963). Омонимы в словарях и омонимия в языке (Homonyms in dictionaries and homonymy in language) // Вопросы теории и истории языка, Л.,
Молошная Т. Н (1960), Алгоритм перевода с английского языка на руссий (Algorithm translation from English to Russian) // Проблемы кибернетики, Moscow.

Общее языкозноние. Внутренняя структура языка (General Linguistics - internal structure of language). Moscow, 1972.

Пророкова В. М (1966). К вопросу о разграничении омонимов и лексико -семантических варианов слова (On the question of distinguishing homonyms from lexical-semantic variants of the word). Дис. канд. филол. наук, М.,

Смирницкий А. И (1948). Некоторые замечния по английской омонимике (Some notes on English homonyms)//ИЯШ, No. 5, c. 10 - 15.

Смирницкий А. И (1959). Лексикология английского языка (English lexicology). Moscow.

Соболева П. А (1980). Словообразовательная полисемия и омонимия (Formative polysemy and homonymy). Moscow.

Тышлер И. С (1988). Омонимия в современном английском языке (Homonymy in modern English). Саратов.

Фалькович М. М (1960). K вопросу об омонимии и полисемии (On the question of homonymy and polysemy) // BЯ, No. 5, c. 85 - 88.

Филлин Ф. Н (1960). Выступление на дискуссии по вопроцам омонимии (Discussion on homonymy) //Л. сб. М,. Вып. 2, с. 59 - 60.

Шайкевич А. Я (1962). Источники лексической омонимии в германских языках (Sources of lexical homonymy in Germanic languages). Диц. канд. филол. наук, М.,

Шанский Н. М (1964). Лексикология совремеххого русского языка (Lexicology of modern Russian). Moscow.

Шендельс Е. И (1955). О грамматической омонимии (On grammatical homonymy) // ИЯШ, o. 5, c. 15 - 25.

\section{Slovak}

Durovic L. (1953). Homonyma v slovniku. Bratislava, p. $63-82$.

\title{
TRỞ LẠI HIỆN TƯợNG ĐỒNG ÂM
}

\author{
Hà Quang Năng \\ Viện Tù điển học và Bách khoa thu, Hàng Chuối, Hai Bà Trung, Hà Nội, Việt Nam
}

Tóm tắt: Đồng âm là một hiện tượng phổ biến trong ngôn ngữ và nhiều nghiên cứu về hiện tượng đồng âm đã được thực hiện. Tuy nhiên, đồng âm nói chung chỉ được hiểu là các đơn vị từ vựng khác nhau có cách phát âm giống hệt nhau hoặc tương tự nhau nhưng ý nghĩa khác nhau. Bài báo này phân tích các quan điểm khác nhau về đồng âm trong các công trình hiện có và trình bày một quan điểm toàn diện, hoàn chỉnh và khoa học hơn về đồng âm trong ngôn ngữ.

Tù khoá: đồng âm đồng tự, hiện tượng đồng âm đồng tự, đồng âm dị tự, hiện tượng đồng âm dị tự, đồng tự dị âm 